\title{
Corrosion Resistance of Nickel Weld Metal Deposited on Carbon Steel In 3.5\% NaCl Solution
}

Amany NagyKamel ${ }^{1}$,Eltohamy.R.Elsharkawy ${ }^{2}$, A. F. Waheed ${ }^{3}$

1,2 Quality control and quality assurance departmentEgyptian nuclear and radiological regulator authority (ENRRA)

3 MetallurgyDepartment, Nuclear Research Center, Atomic Energy Authority, Cairo, Egypt

\begin{abstract}
Dissimilar metal welding is frequently used to join carbon steels to other materials such as nickel metal. This approach is most often used where a transition in mechanical properties and/or performance in service are required. The power generation industry uses dissimilar metal welding extensively to reduce material costs and enhance performance in elevatedtemperature applications.Anodic polarization curves for deposited as weldcondition of $\mathrm{Ni}$ weld metal on carbon steel in $3.5 \% \mathrm{NaCl}$ solution having neutral $\mathrm{pH}$ are studying. Anodic polarization curve for thermal aging of $\mathrm{Ni}$ weld metal for different agingtimes50,500 and $1000 \mathrm{hr}$ at $550^{\circ} \mathrm{Care}$ also recorded. The results indicated that the corrosion current of the $\mathrm{Ni}$ weld metal on carbon steel increases as aging time increase,also the grain size of the deposited Nickel increase during thermal aging for different times 50, 500 and 1000 hours respectively
\end{abstract}

\section{1-Introduction:}

Welds between different metals are called Dissimilar Metal Weld (DMW). Dissimilar metal welding (DMW) has become a critical technology in many areas [1-2]. Nickel-based filler metal has superior corrosion resistance, thus are used frequently in applications requiring dissimilar welding. They are used in a variety of joint involving carbon steel. These welds are commonly used in plants of energy generation, chemical and petrochemical industries and nuclear power plants. In nuclear power plants DMWs are used in safety class systems of all Pressurized Water Reactors (PWR) and "Water Water Energy Reactor" WWER plants. DMWs are generally designed and fabricated to high quality standards [3-4]. However some instances of flaws and/or leakages in operation with nickel alloys have been reported[5]. It is difficult to detect the potential damage with in-service inspectionsystems because of the dendritic nature of the weld, geometric factors, component form and accessibility[6]. Investigations of potential degradation mechanisms, integrity assessment methods have been performed in many developments nuclear center [7-8]. The weld should havecorrosion/oxidation resistance equal to the least resistant base metal being joined. It is fortunate that in most all instances the weld will be of a higher alloy content (better corrosion and oxidation resistance) than the least resistant base metal being joined[9]. When a DMW is in an environment where the liquid can be an electrolyte, the weld metal should be cathode to (more corrosion resistant than) both base metals. If the weld is anodic (less corrosion resistant), it suffers accelerated galvanic corrosion due to area effects [10-11].

The aim of the present work is the study of the performance of the Ni welds deposited on carbon steel in aggressive media, namely $3.5 \% \mathrm{NaCl}$ and the effect of its heat treatment on the performance. 


\section{2-Experimental work:}

The experimental investigation was carried out to evaluate the corrosionperformance ofweldmentsmanufactured by manual shielded metal arc welding (SMAW) processes withpure $\mathrm{Ni}$ welding electrode.

\subsection{Materials:}

\subsubsection{Material of plates:}

The chemical composition of the used plate of carbon steels are givenin Table (1).

Table(1) Chemical composition of the used plate of carbon steel

\begin{tabular}{|l|l|l|l|l|r|r|r|r|r||}
\hline $\begin{array}{l}\text { Element } \\
\%\end{array}$ & $\mathbf{C}$ & $\mathbf{C r}$ & $\mathbf{N i}$ & $\mathbf{M n}$ & $\mathbf{S i}$ & $\mathbf{P}$ & $\mathbf{S}$ & $\mathbf{M o}$ & $\mathbf{F e}$ \\
\hline $\begin{array}{l}\text { Carbon } \\
\begin{array}{l}\text { Steel } \\
\text { (CS) }\end{array}\end{array}$ & 0.2 & 0.01 & 0.01 & $\begin{array}{l}1.3 \\
7\end{array}$ & $\begin{array}{c}0 . \\
23\end{array}$ & $\begin{array}{r}0.0 \\
2\end{array}$ & $\begin{array}{l}0.00 \\
8\end{array}$ & 0.005 & Basis \\
\hline
\end{tabular}

Figure(1) Carbon steel with Welded metal Ni [12 ].

\subsubsection{Weld metal:}

The type of coated electrodes of class AWS (American Welding Society) was used in the welding experiments, thetype is E-Ni, with diameter $\phi=4 \mathrm{~mm}$. The chemical composition of the used electrode is shown in Table (2).

The (SMAW) process was used to prepare acladded-carbon steel with Ni layers, which were welded to form dissimilar joints with Ni filler metal as shown in Figure (1).

Table(2)Chemical composition of the Ni electrode

\begin{tabular}{|c|c|c|c|}
\hline Element\% & $\mathbf{C}$ & Ni & Fe \\
\hline Ni Electrode & 0.5 & Basis & 1 \\
\hline
\end{tabular}

\subsection{Thermal aging procedure:}

Weld metal specimens (both cladded and welded joints) were subjected to an aging temperature of $550^{\circ} \mathrm{C}$ for various holding times ranging from 50 to $1000 \mathrm{hr}$ followed by air- 
cooling, in order to simulate working conditions. The effect of this isothermal thermal aging on microstructure was investigated for the cladded carbon steels and compared with as welded condition. The thermal aging process was performed in a muffle furnace which is automatically controlled with an accuracy of $\pm 5^{\circ} \mathrm{C}$. Ni-NiCr thermocouple attached to a digital thermal indicator was used to check the temperatures at the furnace throughout the holding time.

\subsection{Metallographic examination:}

Metallographic examination was carried out for the weld deposits (Ni layers).The specimens were prepared by grinding under water on rotating disc, using abrasive paper with grades ranging from 180 to 2000. Then polished to mirrored surface by using diamond paste with grades 3 and 1 micron. Nickel was etched with $30 \mathrm{ml} \mathrm{HNO}_{3}$ and $70 \mathrm{ml} \mathrm{H}_{2} \mathrm{O}$ by immersion at room temperature for 5 to 20 second, Specimens were rinsed with alcohol and dried with hot air. An optical microscope (OM) was used for microstructural examination.

\subsection{Microhardness test:}

A Vickers microhardness testing machine was used to measure at least five-hardness values on the studied weld deposit specimens(cladded) and the as weld and after heat treatment conditions. Tests were carried out, also for thesurface Ni layer welded specimens. The applied load was $300 \mathrm{~g}$ and the indentation time was 30 second according to ASTM E92-72.

\subsection{Electrochemical Corrosion testing:}

Prior to corrosion behavior studies, the samples were ground on $\mathrm{SiC}$ grinding papers from 240 till 1000 grade, followed by polishing on polishing lapped cloth using $1 \mu \mathrm{m}$ diamondsuspension. Then the polished samples were degreasing with ethanol before immersion in thetest solution. The electrochemical corrosion behavior of the samples was studied by applying thePotentiodynamic polarization technique using a potentiostat (Electrochemical ImpedanceAnalyzer, Model 6310) interfaced to a computer and a threeelectrode cell with the sample asa working electrode of exposed area $100 \mathrm{~mm} 2$, a saturated calomel reference electrode (SCE), carbon electrode as counter electrode. The testing media was $3.5 \% \mathrm{NaCl}$ prepared from duple distilled water and reagent grade salt. The carbon steel part was covered with plastic tap to avoid the galvanic action.

\section{3-Results and discussion:}

The microstructure of nickel metalwelded-carbon steel in the as weld condition, aging times 50,500 and $1000 \mathrm{hr}$ are shown in Figure (2).It reveals austenitic matrix with the presence of fine precipitates within the austenite matrix. The microstructure of nickel alloys shows assolidified dendritic microstructure with recrystallisationfeatures [12]. C.R. Das, et al [13] found that the microstructure of ERNiCr-3 weld shows as-solidified dendritic microstructure with recrystallisationfeatures. It also shows that in the multipass weld the dendritic microstructure has changed to recrystallisedequiaxed grains. The role of carbides in super alloys is complex and dynamic. Most investigators believe that carbides do exert a significant and beneficial effect on rupture strength at elevated temperatures. In addition, it is quite clear that carbide morphology can influence ductility, and also that carbides can influence the chemical stability of the matrix through the removal of reacting elements. The three main types of carbides found in nickel-based alloy are $\mathrm{MC}, \mathrm{M}_{23} \mathrm{C}_{6}$ and $\mathrm{M}_{6} \mathrm{C} . \mathrm{Cr}_{7} \mathrm{C}_{3}$ can also be present but is rare [14]. Since $\mathrm{M}_{6} \mathrm{C}$ carbides are stable at higher temperatures than $\mathrm{M}_{23} \mathrm{C}_{6}$ carbides, $\mathrm{M}_{6} \mathrm{C}$ is more beneficial as a grain boundary precipitate to control grain size in the wrought alloy [14]. The microstructure of weld metal structure has no major changes after 50 $\mathrm{hr}$ aging the zone of retained austenite increased with increasing aging time, this in agreement 
with R. Anand et al [15], it is clear as that as the aging time increasethe grain size of the $\mathrm{Ni}$ part increase, Nickel base exhibit a complex precipitation behavior at elevated temperatures, during welding, furthermore, the precipitation behavior will depend upon the nickel content and the final temperature [16].
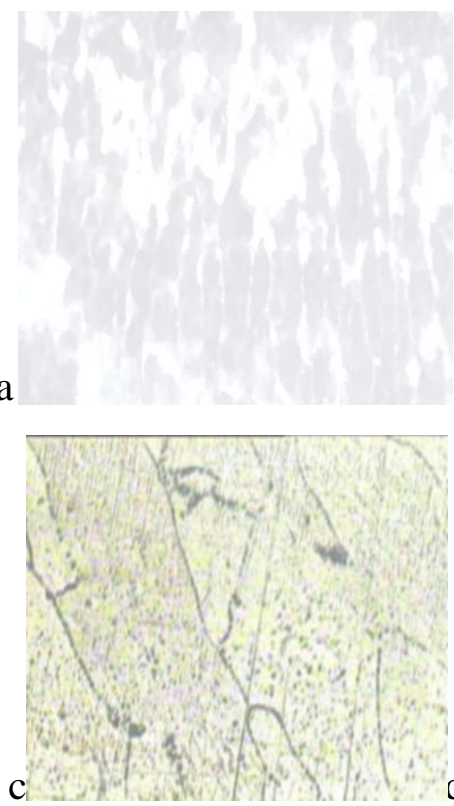

b
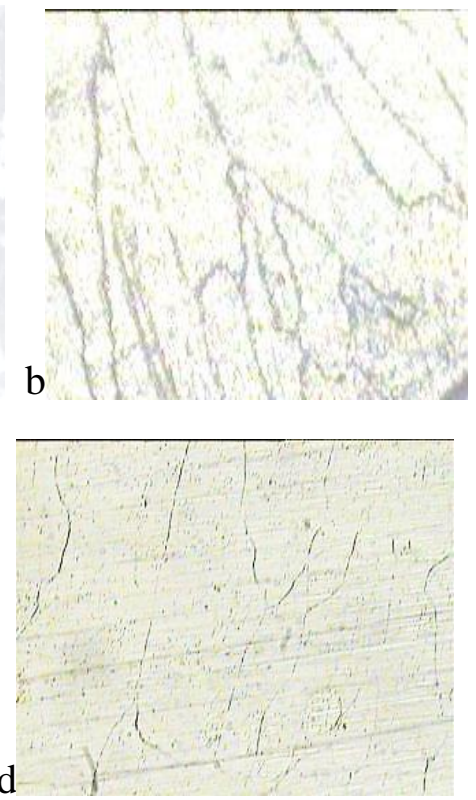

Figure (2) Optical micrograph showing the microstructure features of Ni weld metal deposited on carbon steel after aging (x200) (a) as weld (b) aging time $50 \mathrm{hr}$ (c) aging time $500 \mathrm{hr}$ and (d) aging time $1000 \mathrm{hr}$.

Microhardness testing machine was used to measure at least five -hardness values on the weld deposit specimens in the as weld and after agingconditions [12].

Figure(3) show the microhardnessprofiles of the mean value forfive measuringsmicrohardness at welded deposits on the as-welded condition and after various aging at $550{ }^{\circ} \mathrm{C}$ times for the Nickel weld metals. The curves show the following results the minimum microhardness at $50 \mathrm{hr}$ and the maximum microhardness at 500hr aging,this increase inmicrohardness may be attributed to the strain hardening that produces large amount of deformation twins as shown in Figure (3)

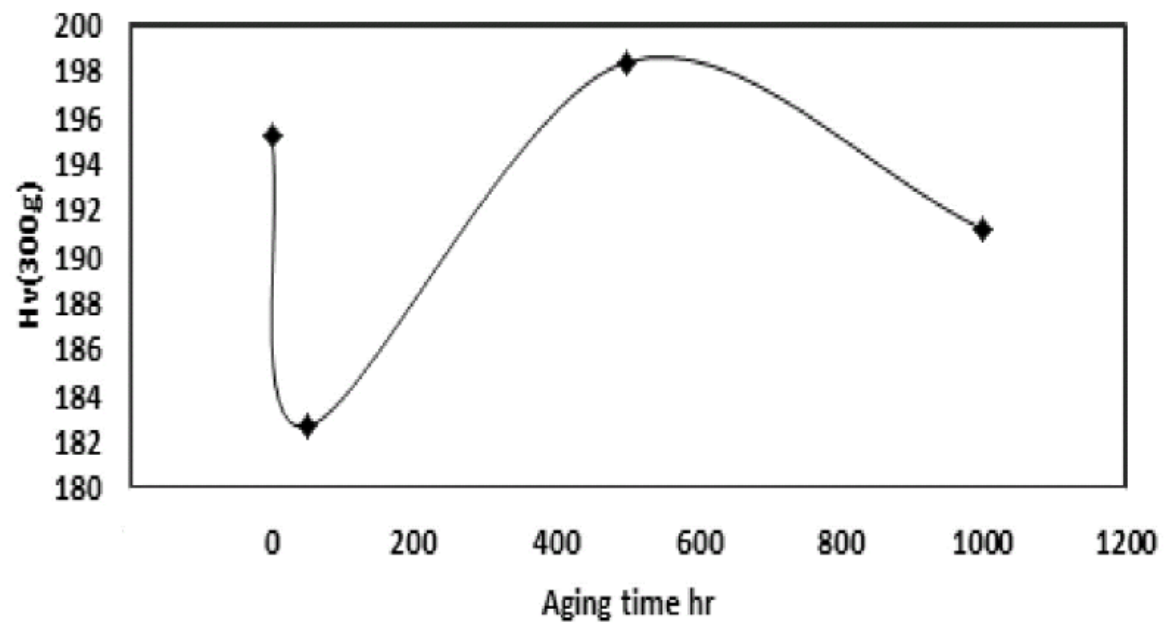

Figure (3) Relation between hardness and aging time hr 
Table 3 Corrosion potential $\mathbf{E}_{\text {corr }}$ and corrosion current density $\mathbf{I}_{\text {corr }}$

\begin{tabular}{|c|c|c|}
\hline Aging condition & $\mathbf{E}_{\text {corr }}(\mathbf{m V})$ & $\mathbf{I}_{\text {corr }}(\boldsymbol{\mu A c m - 2})$ \\
\hline As weld & -181 & 38.68 \\
\hline $\mathbf{5 0} \mathbf{~ h r}$ & -473.2 & 20.78 \\
\hline $\mathbf{5 0 0 h r}$ & -469 & 7.6 \\
\hline $\mathbf{1 0 0 0 h r}$ & -473.6 & 8.922 \\
\hline
\end{tabular}

The corrosion current density $\mathrm{I}_{\text {corr }}$ and corrosion potential $\mathrm{E}_{\text {corr }}$ of the steel tested,which were determined (Table3) by potentiodynamic technique. From these data, one maygenerally evaluate the corrosion properties of $\mathrm{Ni}$ at different conditions ofaging.

The electrochemical tests were established by usingPotentiodynamic technique. Anodic polarization curves for deposited as weld and heat treated $\mathrm{Ni}$ weldmetal in $3.5 \% \mathrm{NaCl}$ solution having never neutral $\mathrm{pH}$ are shown in Figures (4-7).

In Figure (4) the as weld Ni weldmetal the corrosion current density was $38.7 \mu \mathrm{A} / \mathrm{cm}^{2}$. The anodic polarization curve shows some irrigators after corrosion potential and the current density increases as potential increases till $50 \mathrm{mv}$, after this potential there is an abrupt increases in current density, which may be due to pits formation then the current density increases till the end of the run. The hardness value of weldmetal was 195.2 HV measured at $300 \mathrm{~g}$ load.

Figure (5) shows the anodic polarization curve for Ni weld metal heat treated for $50 \mathrm{hr}$ at 550 ${ }^{\circ} \mathrm{C}$, the corrosion currentdensity was $20.8 \mu \mathrm{A} / \mathrm{cm} 2$, the current density increases moderately till $-300 \mathrm{mv}$, after that the current density increases abruptly till the end of the run. The corrosion current which is lower than that of as weld $\mathrm{Ni}$, but the potential is more negative. The hardness of this weldmetal is $182.67 \mathrm{Hv}$ at $300 \mathrm{~g}$ load.

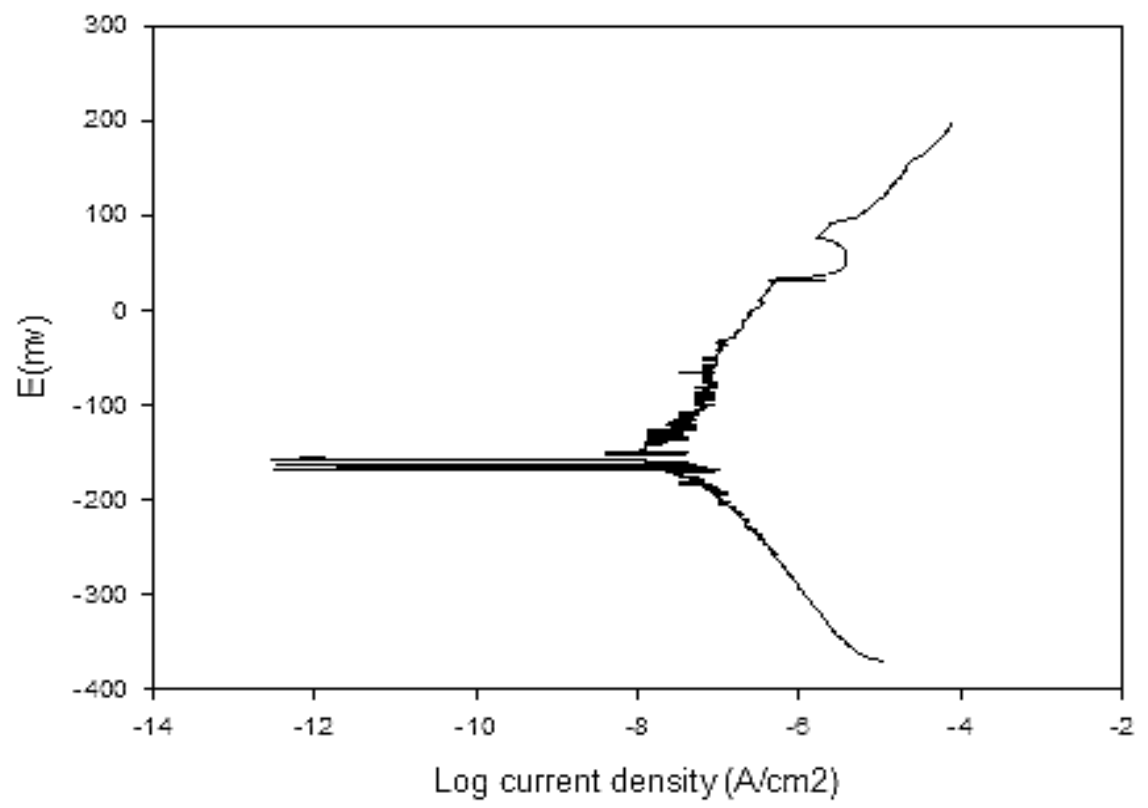

Figure (4) Anodic polarization curve of deposited Ni weld metal as weld condition 


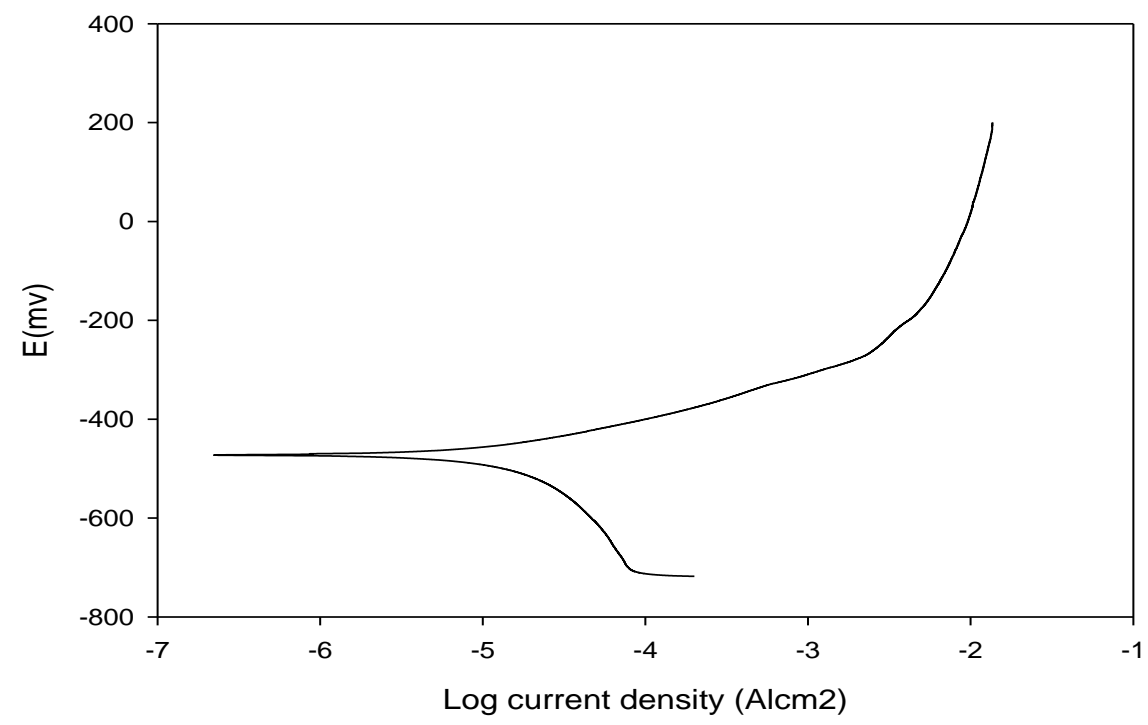

Figure (5) Anodic polarization curve ofdeposited Ni weld metal aging for $50 \mathrm{hr}$ at $550{ }^{\circ} \mathrm{C}$

Figure (6) shows the anodic polarization curve for $\mathrm{Ni}$ weld metal heat treated for $500 \mathrm{hr}$ at $550{ }^{\circ} \mathrm{C}$, the corrosion current density was $8.9 \mu \mathrm{A} / \mathrm{cm}$ 2in this case, and the current density increases steadily with content rate to the end of the experiment the hardness in this case was 198.4 Hv.

Figure (7) shows the anodic polarization curve for Ni weld metal heat treat for $1000 \mathrm{hr}$ at 550 ${ }^{\circ} \mathrm{C}$, the corrosion current was $7.6 \mu \mathrm{A} / \mathrm{cm} 2$. In this case the current density increases after corrosion potential with high rate. The hardness was 191.175.

For all heat treated $\mathrm{Ni}$ weld as the heat aging increases the corrosion potential become more negative as compared to as weld one.

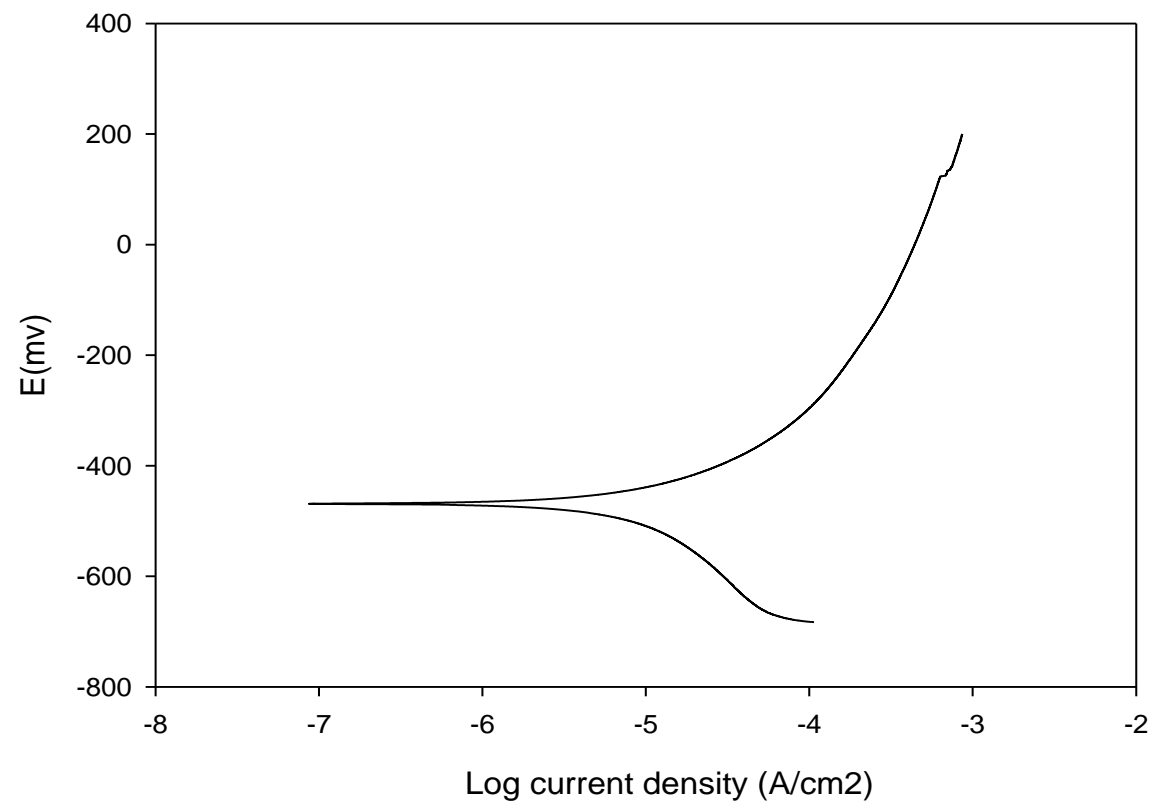

Figure (6)Anodic polarization curve ofdeposited Ni weld metal aging for $500 \mathrm{hr}$ at $550{ }^{\circ} \mathrm{C}$ 


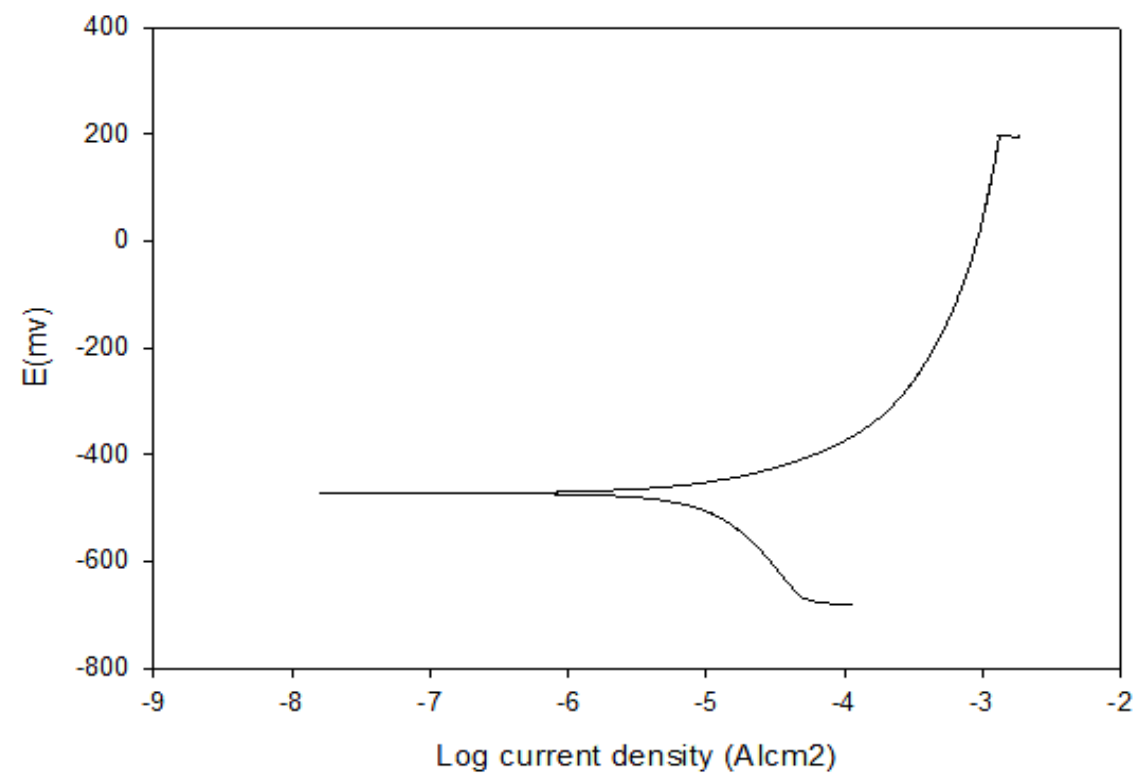

Figure (7) Anodic polarization curve of deposited Ni weld metal aging for $1000 \mathrm{hr}$ at $550{ }^{\mathrm{O}} \mathrm{C}$

\section{Conclusion:}

The study of the corrosion performance of the as weld and heat treatment of deposited Nickel showed that with aging time increases the grain size of the deposited Nickel increase.Also, as the aging time increases the corrosion current density decreases after $50 \mathrm{hr}$ and $500 \mathrm{hr}$, and the potential shifts toward more negative values.

\section{References:}

[1] Rowe, M. D., T. W. Nelson, and J. C. Lippold. "Hydrogen-induced cracking along the fusion boundary of dissimilar metal welds." WELDING JOURNAL-NEW YORK- 78 (1999): 31-s.

[2] Hwang, Jeong Ho, JuHwa Lee, and Dong Ho Bae. "Welding residual stress effect of the fatigue strength at dissimilar material weld between Alloy617 and $12 \mathrm{Cr}$ steel." International Journal of Modern Physics B 32, no. 19 (2018): 1840053.

[3] Gittos, M., and T. Gooch. "The interface below stainless steel and nickel-alloy claddings." Carbon 2 (1992): 4Cr-1Mo.

[4]Seifert, H. P., S. Ritter, T. Shoji, Q. J. Peng, Y. Takeda, and Z. P. Lu. "Environmentallyassisted cracking behaviour in the transition region of an Alloy182/SA $508 \mathrm{Cl} .2$ dissimilar metal weld joint in simulated boiling water reactor normal water chemistry environment." Journal of Nuclear materials 378, no. 2 (2008): 197-210.

[5] Xu, Jian, Zihao Wang, and Tetsuo Shoji. "Effects of hydrogen on corrosion of pure Ni in high temperature water." Corrosion Science 122 (2017): 123-129

[6] Yang, Jianqiao, Shuzhong Wang, DonghaiXu, Yang Guo, Chuang Yang, and Yanhui Li. "Effect of ammonium chloride on corrosion behavior of Ni-based alloys and stainless steel in supercritical water gasification process." International Journal of Hydrogen Energy 42, no. 31 (2017): 19788-19797.

[7]Okoro, Sunday Chukwudi, Melanie Montgomery, FlemmingJappeFrandsen, and Karen Pantleon."Influence of preoxidation on high temperature corrosion of a Ni-based alloy under conditions relevant to biomass firing." Surface and Coatings Technology 319 (2017): 76-87. 
[8] El-Awadi, G. A., S. Abdel-Samad, and Ezzat S. Elshazly. "Hot corrosion behavior of Ni based Inconel 617 and Inconel 738 superalloys." Applied surface science 378 (2016): 224230.

[9]Lu, B. T., et al. "Pitting and stress corrosion cracking behavior in welded austenitic stainless steel." Electrochimicaacta 50.6 (2005): 1391-1403.

[10] Li, L., et al. "Effect of $\mathrm{pH}$ on pitting corrosion of stainless steel welds in alkaline salt water." Construction and Building Materials68 (2014): 709-715.

[11]Karki, V., and M. Singh. "Investigation of corrosion mechanism in Type 304 stainless steel under different corrosive environments: A SIMS study." International Journal of Mass Spectrometry 421 (2017): 51-60.

[12]Amany NagyKamel..el "Quality Evaluation of Structural Integrity of Welds" Thesis for the Degree of Doctor of Philosophy of Science in Mechanical Production Engineering, Banha University, Shoubra Faculty of Engineering, Egypt, (2012).

[13] Das, C. R., A. K. Bhaduri, G. Srinivasan, V. Shankar, and S. Mathew. "Selection of filler wire for and effect of auto tempering on the mechanical properties of dissimilar metal joint between 403 and 304L (N) stainless steels." Journal of materials processing technology 209, no. 3 (2009): 1428-1435.

[14]Ezugwu, E. O., Z. M. Wang, and A. R. Machado. "The machinability of nickel-based alloys: a review." Journal of Materials Processing Technology 86, no. 1-3 (1999): 1-16.

[15] Anand, R., C. Sudha, V. Thomas Paul, S. Saroja, and M. Vijayalakshmi. "Microstructural changes in Grade 22 ferritic steel clad successively with Ni-based and 9Cr filler metals." Weld. J 89, no. 4 (2010): 65s-74s.

[16] Ryl, Jacek, Joanna Wysocka, and KazimierzDarowicki. "Determination of causes of accelerated local corrosion of austenitic steels in water supply systems." Construction and Building Materials 64 (2014): 246-252 